\title{
EVALUATION OF THE MICROBIAL LOAD AND IDENTIFICATION OF POSSIBLE SOURCES OF CONTAMINATION OF RAW COW'S MILK IN JOANNA, BLACK BUSH POLDER, REGION 6, GUYANA
}

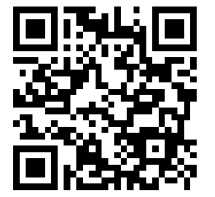

\author{
Roshnie Singh 1, Dharamdeo Singh 2, Phillip Da Silva ${ }^{1}$, Gomathinayagam \\ Subramanian ${ }^{3}$ 区 \\ ${ }^{1}$ Faculty of Natural Sciences, University of Guyana, Berbice Campus, Tain, Guyana \\ 2 Faculty of Agriculture Science, University of Guyana, Turkeyen Campus, Georgetown, Guyana \\ ${ }^{*} 3$ Faculty of Agriculture Science, University of Guyana, Berbice Campus, Tain, Guyana
}

DOI: https://doi.org/10.29121/granthaalayah.v8.i5.2020.44

Article Type: Research Article

Article Citation: Roshnie Singh, Dharamdeo Singh, Phillip Da Silva, and Gomathinayagam Subramanian. (2020). EVALUATION OF THE MICROBIAL LOAD AND IDENTIFICATION OF POSSIBLE SOURCES OF CONTAMINATION OF RAW COW'S MILK IN JOANNA, BLACK BUSH POLDER, REGION 6, GUYANA. International Journal of Research -GRANTHAALAYAH, 8(5), 22-31.

https://doi.org/10.29121/granthaa layah.v8.i5.2020.44

Received Date: 02 May 2020

Accepted Date: 25 May 2020

Keywords:

Escherichia Coli

Aerobic Bacteria

Raw Cow's Milk

Contamination

Environment

Predisposed

\section{ABSTRACT}

Milk is one of the main sources of nutrients to animals, but due to its high water activity, it serves as an ideal medium for the growth of microorganisms. The purpose of this research was to evaluate the microbial load in raw cow's milk and to identify the possible sources of raw milk contamination in Joanna. Fifteen (15) raw milk samples were collected randomly according to the simple random sampling method and farmers were interviewed. Raw milk samples were analysed for Escherichia coli and aerobic bacteria. From the 15 samples of raw milk, contamination with E. coli (93.33\%) and aerobic bacteria (100\%) was observed. Also, several factors, milk handling practices, unhygienic practices, extensive farming systems, and lack of general zoonoses exposure practices and awareness, predisposed raw milk to microbial contamination. This research concluded that the quality of milk was unsatisfactory since it was heavily contaminated with bacteria. It is recommended that there should be an increase in the agriculture extension education and awareness programme to help improve milk quality.

\section{INTRODUCTION}

Milk is one of the main sources of nutrients for animals. It is a source of high-quality proteins, vitamins, and minerals. Since cow's milk is an excellent high-quality food, it offers important health benefits such as building teeth and bones, enhancing vasodilation and reducing blood pressure [1], however, due to its high water activity, it serves as an ideal medium for the growth of microorganisms [2]. When the milk is produced from a healthy lactating cow,

(C) 2020 The Author(s). This is an open access article distributed under the terms of the Creative Commons Attribution License, which permits unrestricted use, distribution, and reproduction in any medium, provided the original author and source are credited. 
it contains some bacteria, such as 500 to 1000 per milliliter, but due to the temperature of storage and time, the quality of milk is altered [3]

Since raw milk is a well-known good medium that supports the growth of several microbes with the resultant spoilage of products or infections in consumers, microbes may gain entry into raw milk directly from dairy cows experiencing sub-clinical or clinical mastitis [4], from the farm environment, particularly the water source [5] and utensils used for the storage of milk on the farm or during transportation. Raw, unpasteurized milk is consumed directly by a large number of people in rural areas and indirectly by a much larger segment of the population via consumption of several types of cheeses. Among the main reasons, people believed that raw milk and its products have advantages or value over the pasteurized one. Being a highly nutritious medium, many bacteria, including spoilage and pathogenic bacteria can grow and propagate in it. Generally, bacteria in the milk can occur through the colonization of the teat canal or an infected udder or gets contaminated at various stages be it from the animal, farmer, dirt, poor handling, and storage of milk, unsanitary utensils or unclean process water [6].

It is estimated that one-third of the developed countries are affected by food-borne diseases which are caused by the consumption of food contaminated with microbial pathogens such as bacteria [7]. Microbial pathogens enter the body through contaminated food or water [8]. Since milk is very perishable, it is an ideal medium for the growth of a wide variety of pathogenic bacteria such as Staphylococcus spp., Listeria spp., Salmonella spp., E. coli spp., Campylobacter spp. among other species. These bacteria pose a serious threat to human health and contribute up to $90 \%$ of all dairy-related diseases [9], [10], [11], [6].

From 2000 to 2006, state public health agencies reported 40 separate outbreaks attributed to raw milk consumption that resulted in nearly 600 illnesses. In December 2005, 18 out of 140 people who reported consuming milk from a cattle farm in Washington became ill with E. coli. Five children (aged 1-13 years old) were hospitalized and 4 of these patients developed Hemolytic Uremic Syndrome. In 2006, E. coli 0157:H7 was again responsible for illness in 6 children in California. There was an increase in the number of E. coli, Campylobacter, and Salmonella cases as more and more children were ill [12].

Several studies conducted globally revealed that E. coli is found in raw cow's milk. According to [13], a crosssectional study was conducted in the Sari city to determine the prevalence and population of $E$. coli with an emphasis on E. coli 0157:H7 in bovine milk around Asosa Town, Western Ethiopia. Out of the 380 raw cow milk samples collected, E. coli was isolated from 129 of the samples.

In another study, [14] investigated the bacterial contamination of raw and pasteurized milk in Sari Township, Iran. The results obtained showed that 42 out of 100 samples of raw cow's milk were contaminated with E. coli, while in the pasteurized samples, 9 out of 100 samples were contaminated with E. coli.

As such, this research evaluated the microbial load in raw cow's milk and identified the possible sources of contamination of raw milk in Joanna, Black Bush Polder, Region 6, Guyana. After laboratory analyses of all samples collected, microbes were found in the raw milk and several factors may have predisposed the milk to microbial contamination.

\section{MATERIALS AND METHODS}

\subsection{SITE OF WORK}

This study was carried out in Joanna, Black Bush Polder and at the University of Guyana, Berbice Campus, John's Science Centre.

\subsection{METHODS}

\subsubsection{QUESTIONNAIRE STUDY}

\section{Ethical Consideration}

Farmers participated in this study voluntarily. The purpose and importance of this research were explained before the interviews. All the information collected from the participants and laboratory results obtained after milk analysis were kept confidential by the researcher and the study participants were anonymised. 
Evaluation of The Microbial Load and Identification of Possible Sources of Contamination of Raw Cow's Milk in Joanna, Black Bush Polder, Region 6, Guyana

\section{Data Collection}

The questionnaire was pilot tested in Region \#5 on five (5) cattle farmers before being issued to participants to determine its validity. All information gathered from the questionnaires was kept in the strictest confidentiality. A simple random sampling was done. The farmers were asked questions in a face-to-face interview. The questionnaire consisted of six (6) sections, each section focusing on different aspects of the dairy cattle farm.

- Section A -Demographic Information

- Section B -Farm Management Practices

- Section C -Milk Handling Practices

- Section D -Hygienic Practices

- Section E-Farming System

- Section F-General Zoonoses Exposure Practices and Awareness

\subsubsection{LABORATORY WORK}

\section{Collection of Samples}

Fifteen (15) milk samples were collected from dairy cattle farmers within the study area. Samples were collected once from farmers. All samples were handled with the best possible care to minimise any incidence of contamination. Milk samples collected were placed in sterile containers and transported in a cooler to John's Science Center Laboratory, where they were analysed.

\subsubsection{MICROBIAL ANALYSIS}

\section{Testing for the Presence of Escherichia Coli.}

\section{Sample Preparation and Inoculation of the Medium}

Weekly samples were aseptically and randomly collected from the designated farmers and transported to the laboratory. Ten milliliters $(10 \mathrm{ml})$ of each sample was homogenised in a sterile sample container with saline solution. Decimal dilutions were prepared $\left(10^{-1}\right.$ to $\left.10^{-6}\right)$. Each dilution was used to inoculate the MacConkey agar using the spread plate method. Plates were incubated at $37^{\circ} \mathrm{C}$ for 48 hours. After incubation, the plates were examined for suspicious colonies of E. coli. E. coli colonies appear pink to red with bile salt precipitate surrounding them on MacConkey agar [15].

\section{Confirmation Test - Indole Test}

Several drops of Indole Spot Reagent were placed on a piece of filter paper. With an inoculating loop, a portion of isolated pink colonies from the MacConkey was picked up and rubbed onto the reagent saturated area of the filter paper. A positive reaction was denoted by the appearance of purple color on the bacterial smear, within 10 seconds. Negative reactions remained colorless or light pink [15].

\section{Counting Colonies and Expression of Results}

Colonies were counted manually. A light source and a magnifying glass were used for making colonies easier to detect. After counting the colonies, multiplication by the appropriate dilution factor to determine the number of colonies forming units per milliliter (CFU/ml) in the original sample was done [15]. Microbial results for the level of Escherichia coli were compared to a guideline for the microbial quality of milk by referring to the National Standard of Iran, code number 2406.

\section{Testing for the Presence of Aerobic Bacteria Sample Preparation and Inoculation of the Medium}

Weekly samples were aseptically and randomly collected from the designated farmers and transported to the laboratory. Ten milliliters $(10 \mathrm{ml})$ of each sample was homogenised in a sterile sample container with saline solution. Serial dilutions were prepared $\left(10^{-1}\right.$ to $\left.10^{-8}\right)$. From each dilution (starting with the last dilution), three sterile nutrient plates were inoculated with $1 \mathrm{ml}$ of the test sample. With the aid of sterile swab, the sample was spread on the media surface and the plates were allowed to dry with their lids on for about 15 minutes. The plates were inverted and 
incubated at $37^{\circ} \mathrm{C}$ under an aerobic condition for 48 hours to allow bacterial growth. A clean sterile pipette was used for each dilution; the procedure was repeated as above with further dilutions up to the first dilution for the remaining test samples [15].

\section{Counting Colonies and Expression of Results}

Colonies were counted manually. A light source and a magnifying glass were used for making colonies easier to detect. After counting the colonies, multiplication by the appropriate dilution factor to determine the number of colonies forming units per milliliter $(\mathrm{CFU} / \mathrm{ml})$ in the original sample was done [15].

Microbial results for the level of aerobic bacteria were compared to Cornell University, Milk Quality Improvement Program, Department of Food Science guideline for the microbial quality of raw cow's milk.

\subsubsection{STATISTICAL ANALYSIS}

All statistical analyses, including the frequency, were conducted using the SPSS Statistics Base 23 program.

\section{RESULTS AND DISCUSSIONS}

\subsection{LEVEL OF CONTAMINATION AT THE FARM LEVEL}

A total of fifteen (15) raw milk samples were collected from cattle farmers within Joanna, Black Bush Polder who are suppliers of raw cows' milk to consumers. The results revealed that $E$. coli was present in over $90 \%$ of the milk samples, while $100 \%$ of the milk samples had aerobic bacteria.

Table 1: The Levels of Contamination of E. coli when compared to the National Standard of Iran, Code Number

\begin{tabular}{|c|c|c|c|c|c|c|c|}
\hline \multicolumn{8}{|c|}{2406} \\
\hline \multirow[t]{4}{*}{ S.N } & \multirow[t]{4}{*}{ Farmer $(\mathrm{CFU} / \mathrm{ml})$} & \multirow[t]{4}{*}{ (LOGCFU/ml) } & \multicolumn{5}{|c|}{ Microbial Quality (CFU/ml) } \\
\hline & & & Excellent & $\begin{array}{c}\text { First } \\
\text { Grade }\end{array}$ & $\begin{array}{c}\text { Second } \\
\text { Grade }\end{array}$ & $\begin{array}{l}\text { Third } \\
\text { Grade }\end{array}$ & Nonstandard \\
\hline & & & $<3 \times 104$ & $\begin{array}{c}3 \times 104- \\
1 \times 105\end{array}$ & $\begin{array}{c}1 \times 105- \\
5 \times 105\end{array}$ & $\begin{array}{c}5 \times 105- \\
1 \times 106\end{array}$ & $>1 \times 106$ \\
\hline & & & 4.477 & $4.477-5$ & $5-5.699$ & $5.699-6$ & 6 \\
\hline 1 & $3.5^{*} 107$ & 7.544 & & & & & $*$ \\
\hline 2 & $2.38 * 108$ & 8.377 & & & & & $*$ \\
\hline 3 & $8.3 * 107$ & 7.919 & & & & & $*$ \\
\hline 4 & $3.8 * 107$ & 7.580 & & & & & $*$ \\
\hline 5 & $5.6 * 107$ & 7.748 & & & & & $*$ \\
\hline 6 & $2.7 * 108$ & 8.431 & & & & & $*$ \\
\hline 7 & $4.8 * 107$ & 7.681 & & & & & $*$ \\
\hline 8 & $2.5^{*} 107$ & 7.398 & & & & & $*$ \\
\hline 9 & $7.4^{*} 107$ & 7.869 & & & & & $*$ \\
\hline 10 & 0 & - & $*$ & & & & \\
\hline 11 & $1.63 * 108$ & 8.212 & & & & & * \\
\hline 12 & $2.8 * 107$ & 7.447 & & & & & $*$ \\
\hline 13 & $2.86 * 108$ & 8.456 & & & & & $*$ \\
\hline 14 & $2 * 108$ & 8.301 & & & & & $*$ \\
\hline 15 & $3.4^{*} 107$ & 7.531 & & & & & $*$ \\
\hline
\end{tabular}

Milk samples tested for the presence of $E$. coli revealed that one (1) $\mathrm{ml}$ of the milk sample contained at least $2.5^{*} 10^{7} \mathrm{CFU} / \mathrm{ml}$. The range of $E$. coli was from $0 \mathrm{Log} \mathrm{CFU} / \mathrm{ml}$ to $8.456 \mathrm{Log} \mathrm{CFU} / \mathrm{ml}$. These results indicated that the number of $E$. coli colonies found in milk is at the nonstandard level according to the National Standard of Iran, Code Number 2406. This study corresponded with [14] who sampled 100 raw milk samples which showed that $42 \%$ of 
Evaluation of The Microbial Load and Identification of Possible Sources of Contamination of Raw Cow's Milk in Joanna, Black Bush Polder, Region 6, Guyana

the milk was contaminated with E. coli and by referring to the grading of raw milk contamination of National Standard of Iran and considering the total bacterial count, the milk attained 8\% nonstandard level.

Table 2: The Levels of Contamination of aerobic bacteria when compared to Cornell University, Milk Quality Improvement Program, Department of Food Science

\begin{tabular}{|c|c|c|c|c|c|}
\hline \multirow{2}{*}{ SN } & Farmer (CFU/ml) & \multirow{2}{*}{ (LOGCFU/ml) } & \multicolumn{3}{|c|}{ Microbial Quality (CFU/ml) } \\
\cline { 4 - 5 } & & & Satisfactorily & Acceptable & Unsatisfactory \\
\cline { 4 - 5 } & & & $<5000$ & $\leq 10,000$ & $>100,000$ \\
\hline & & & $<3.699$ & $\leq 4$ & $>5$ \\
\hline 1 & $4.5^{*} 10^{7}$ & 7.653 & & & $*$ \\
\hline 2 & $1.72^{*} 10^{8}$ & 8.236 & & & $*$ \\
\hline 3 & $7.1^{*} 10^{7}$ & 7.851 & & & $*$ \\
\hline 4 & $1.59^{*} 10^{8}$ & 8.201 & & & $*$ \\
\hline 5 & $3.2^{*} 10^{8}$ & 8.505 & & & $*$ \\
\hline 6 & $9.2^{*} 10^{8}$ & 8.964 & & & $*$ \\
\hline 7 & $>500$ & & & & $*$ \\
\hline 8 & $2.7^{*} 10^{7}$ & 7.431 & & & $*$ \\
\hline 9 & $6^{*} 10^{8}$ & 8.778 & & & $*$ \\
\hline 10 & $2.84^{*} 10^{8}$ & 8.453 & & & $*$ \\
\hline 11 & $7.3^{*} 10^{9}$ & 9.863 & & & $*$ \\
\hline 12 & $5.2^{*} 10^{7}$ & 7.716 & & & $*$ \\
\hline 13 & $1.3^{*} 10^{7}$ & 7.114 & & & $*$ \\
\hline 15 & $4.5^{*} 10^{8}$ & 8.653 & & & $*$ \\
\hline
\end{tabular}

During this research, it was found that aerobic bacteria were present in all fifteen (15) milk samples tested. One (1) sample exceeded five hundred (500) colonies of aerobic bacteria which indicated that this sample was extremely contaminated. This may have been due to the unhygienic condition of the farm during milk production. The milk samples tested showed a high level of aerobic bacteria ranging from $7.114 \mathrm{Log} \mathrm{CFU} / \mathrm{ml}$ to $9.934 \mathrm{Log}$ CFU/ml. A similar study was conducted in Hawassa, Southern Ethiopia by [16], which showed that the overall mean of Aerobic mesophilic bacterial count was 4.57, 7.28 and $10.28 \log 10 \mathrm{CFU} / \mathrm{ml}$ for milk samples collected directly from the udder, from storage containers, and distribution containers upon arrival at selling points, respectively. Contamination occurs as a result of the unhygienic practices followed during milk production and insufficient cleaning of the udder.

\subsection{SOURCES OF CONTAMINATION}

Milk is extremely susceptible to microbial contamination as soon as it is extracted from the cow's udder. Several factors at the farm level may have predisposed milk to microbial contamination such as milk handling practices, unhygienic practices, extensive farming systems, and lack of general zoonoses exposure practices and awareness as shown in table 3, 4, 5, 6 and 7 respectively.

\subsubsection{FARM MANAGEMENT PRACTICES}

Table 3: Possible Sources of Contamination at the Farm Level

\begin{tabular}{|c|c|c|c|}
\hline Description & Response & Percentage (\%) & Frequency \\
\hline Are your animals housed at night? & $\begin{array}{l}\text { Yes } \\
\text { No }\end{array}$ & $\begin{array}{l}73.3 \\
26.7\end{array}$ & $\begin{array}{c}11 \\
4\end{array}$ \\
\hline If yes, what type of floor/bedding are they in? & $\begin{array}{l}\text { Natural Earth } \\
\text { Covered with } \\
\text { Manure }\end{array}$ & $\begin{array}{c}60 \\
13.3\end{array}$ & $\begin{array}{l}9 \\
2\end{array}$ \\
\hline
\end{tabular}


Roshnie Singh, Dharamdeo Singh, Phillip Da Silva, and Gomathinayagam Subramanian

\begin{tabular}{|c|c|c|c|}
\hline $\begin{array}{c}\text { Did you introduce any NEW animal(s) into your cattle } \\
\text { herd IN THE PAST YEAR? }\end{array}$ & $\begin{array}{l}\text { Yes } \\
\text { No }\end{array}$ & $\begin{array}{l}40 \\
60\end{array}$ & $\begin{array}{l}6 \\
9\end{array}$ \\
\hline $\begin{array}{c}\text { Was the new animal(s) tested for ANY diseases before } \\
\text { the introduction? }\end{array}$ & $\begin{array}{l}\text { Yes } \\
\text { No }\end{array}$ & $\begin{array}{l}13.3 \\
26.7\end{array}$ & $\begin{array}{l}2 \\
4\end{array}$ \\
\hline
\end{tabular}

Table 3 highlights the milk handling practices which suggest that the housing of the animals and the type of floor used may contribute to milk contamination since bacteria are ubiquitous. Also, the introduction of new animals without testing it for diseases may pass disease from one cow to another, through contamination of fodder or drinking and bathing water with their saliva or feaces. According to a study conducted by [17], teats and udders of cows inevitably become contaminated while they are lying in stalls or when allowed in dirty environments. Used organic bedding has been shown to harbor large numbers of microorganisms which often exceed 100,000,000 to $10,000,000,000$ per gram of bedding. The number of bacterial counts depends on the extent of soiling of the teat surface and the udder preparation processes employed. Milking heavily soiled cows could potentially result in milk counts exceeding $10,000 \mathrm{CFU} / \mathrm{ml}$.

\subsubsection{MILK HANDLING PRACTICES AT THE FARM LEVEL}

Table 4: Possible Sources of Contamination at the Farm Level

\begin{tabular}{|c|c|c|c|}
\hline \multicolumn{1}{|c|}{ Description } & Response & $\begin{array}{c}\text { Percentage } \\
\text { (\%) }\end{array}$ & Frequency \\
\hline What method of milking is being used? & Manual & 100 & 15 \\
\hline How often do you milk your cows? & veryday & 80 & 12 \\
& Twice a week & 6.7 & 1 \\
\hline When are cows milked? & Weekly & 6.7 & 1 \\
\hline Where is milking being done? & Four times per week & 6.7 & 15 \\
\hline & In the farm & 100 & 12 \\
\hline What is used to collect milk after milking the cows? & In the pen & 20 & 3 \\
\hline After you finished milking the cows, how do you prevent & Pots & 40 & 9 \\
\hline the milk from spoiling before it is delivered to the & Btored in the refrigerator & 73.3 & 11 \\
\hline customers? & & 26.7 & 4 \\
\hline If selling is being done, when is the milk sold? & Immediately & 53.3 & 8 \\
& 2 hours after milking & 40 & 6 \\
\hline Do you sell any remaining milk the following day? & 4 hours after milking & 6.7 & 1 \\
\hline If yes to the above question, how do you keep the milk & Yes & 26.7 & 4 \\
from spoiling? & Store in a refrigerator & 33.3 & 5 \\
\hline What type of container(s) do you use for selling milk? & Wide necked-aluminum & 13.3 & 5 \\
\hline
\end{tabular}

Also, table 4 emphasizes on milk handling practices. It was further found that all farmers utilised the manual method of milking cows, which may be a contributing source of microbial contamination, due to poor hygienic practices as mentioned in table 5. Moreso, most farmers milked their cows on the farm, without taking into consideration the number of impurities in the area that pollutes milk. Milk is often collected in buckets. These buckets are not sterilised before collection, therefore, it may contain microbes that cause the samples tested to show such a high presence of aerobic bacteria. According to the farmers, milk collected is locked in a container to prevent spoilage. During milking, bacteria on the inside or outside of the cow's udder gets into the milk [18]. 
Evaluation of The Microbial Load and Identification of Possible Sources of Contamination of Raw Cow's Milk in Joanna, Black Bush Polder, Region 6, Guyana

Since milk is vulnerable to contamination, locking it in a container for a long period of time will cause the bacteria to increase in their numbers at a faster rate. Farmers who sold the remaining milk on the following day, tend to place it in the refrigerator during the night. Refrigeration tends to minimise bacterial growth. Refrigeration is among the most important factors for maintaining the safety of milk. The growth of bacteria will not occur at a rate below $45^{\circ} \mathrm{F}$. However, temperatures below $40^{\circ} \mathrm{F}$ are ideal to protect the milk's quality [19]. Milk is being sold in used water bottles by many farmers. These bottles contribute to the contamination of milk since many farmers do not sterilise the bottles. Once the bottles are exposed to the air, they get into contact with microbes easily.

A similar study conducted by [20] revealed that the milking environment was found to predispose raw cow milk to microbial contaminations. The areas in which the study was conducted appeared rather dirty; the use of cold water in the washing of the udder and the poorly washed plastic containers may have led to high contaminations. The plastic milk containers always appeared dirty and some were discolored due to insufficient cleaning.

\subsubsection{HYGIENIC PRACTICES AT THE FARM LEVEL}

Table 5: Possible Sources of Contamination at the Farm Level

\begin{tabular}{|c|c|c|c|}
\hline Description & Response & Percentage (\%) & Frequency \\
\hline Do you use gloves when milking cows? & $\begin{array}{l}\text { Yes } \\
\text { No }\end{array}$ & $\begin{array}{l}30 \\
80\end{array}$ & $\begin{array}{c}3 \\
12\end{array}$ \\
\hline $\begin{array}{l}\text { Do you wash the cow's udder before milking the } \\
\text { cow? }\end{array}$ & $\begin{array}{l}\text { Yes } \\
\text { No }\end{array}$ & $\begin{array}{l}46.7 \\
53.3\end{array}$ & $\begin{array}{l}7 \\
8\end{array}$ \\
\hline $\begin{array}{l}\text { Do you use any disinfectant to wash the cow skin or } \\
\text { udder area? }\end{array}$ & $\begin{array}{l}\text { Yes } \\
\text { No }\end{array}$ & $\begin{array}{l}13.3 \\
86.7\end{array}$ & $\begin{array}{c}2 \\
13\end{array}$ \\
\hline $\begin{array}{l}\text { What is the source of drinking water available to } \\
\text { your cattle? }\end{array}$ & $\begin{array}{c}\text { Tap water } \\
\text { Water from canals }\end{array}$ & $\begin{array}{l}20 \\
80\end{array}$ & $\begin{array}{c}3 \\
12 \\
\end{array}$ \\
\hline Do the cattle bathe with the same water? & $\begin{array}{l}\text { Yes } \\
\text { No }\end{array}$ & $\begin{array}{l}73.3 \\
26.7\end{array}$ & $\begin{array}{c}11 \\
4\end{array}$ \\
\hline What is the practice when a cow is sick? & $\begin{array}{c}\text { Milking } \\
\text { Not-milking }\end{array}$ & $\begin{array}{l}73.3 \\
26.7\end{array}$ & $\begin{array}{c}11 \\
4\end{array}$ \\
\hline $\begin{array}{l}\text { How is your cleaning routine for the milk } \\
\text { containers? }\end{array}$ & $\begin{array}{l}\text { Cleaning just before } \\
\text { putting in milk } \\
\text { Cleaning after delivery } \\
\text { of milk } \\
\text { Twice a day }\end{array}$ & $\begin{array}{l}53.3 \\
13.3 \\
33.3\end{array}$ & $\begin{array}{l}8 \\
2 \\
5\end{array}$ \\
\hline
\end{tabular}

Most farmers are unhygienic. The majority of farmers (80\%) do not use gloves for milking cows, nor use disinfectants to wash the cows' udder before milking. According to [17], bacteria are found in the udder and on the outside, therefore, it can get into contact with the milk, hence making it impure. Also, most cattle consumed water from the canal contaminating it with their saliva and bathe with the same water. Therefore, the bodies that are dirty with feaces is being washed into the canal, further contributing to microbial contamination of the udder.

The results obtained from a study conducted by [21] showed that cattle water sources can serve as environmental reservoirs for E. coli 0157 and as a long-term source for cattle infection. This also corresponds to studies conducted by [22] where there was an association between the presence of $E$. coli 0157 in cattle water sources and the infection status of cattle drinking from these sources. Very often infected cattle contaminate their water source with faeces or saliva containing E. coli 0157.

When the cows are sick, the majority of the farmers tend to milk them, because if the milk is kept in the udder, the udder becomes swollen, contributing to the animal's discomfort. Once the production of milk is high, and milking is not being done, the pressure is built up in the udder, which can lead to infections such as mastitis [23]. Also, many farmers admitted that they cleaned their containers just before putting in milk. Left-over milk in the containers may have caused a significant increase in microbes. Washing of the containers just before putting in milk, may not remove all the microbes. 
Roshnie Singh, Dharamdeo Singh, Phillip Da Silva, and Gomathinayagam Subramanian

\subsubsection{FARMING SYSTEMS}

Table 6: Possible Sources of Contamination at the Farm Level

\begin{tabular}{|c|c|c|c|}
\hline Description & Response & Percentage (\%) & Frequency \\
\hline What farming systems are you practicing? & Intensive & 6.7 & 1 \\
& Semi-intensive & 13.3 & 2 \\
& Extensive & 80 & 12 \\
\hline Where do you commonly graze your cattle? & Dumpsite & 6.7 & 1 \\
& Open area & 93.3 & 14 \\
\hline Do you keep other animals apart from cattle? & Yes & 53.3 & 8 \\
& No & 46.7 & 7 \\
\hline
\end{tabular}

Further, many farmers allowed their cattle to graze extensively. While they are in the field grazing, they may forage on contaminated fodder. The fodder may have been contaminated due to other animals grazing in the same area. These animals tend to defecate in the said area. Feaces are a major source of $E$. coli. Therefore, plants and grasses found within the vicinity become contaminated with E. coli. Also, $80 \%$ of the farmers never conducted any routine screening and prevention of diseases on their cattle, therefore, they are not aware if the animals have any disease. This may be due to a lack of knowledge of zoonoses and zoonotic diseases.

\subsubsection{GENERAL ZOONOSES EXPOSURE PRACTICES AND AWARENESS}

Table 7: Possible Sources of Contamination at the Farm Level

\begin{tabular}{|c|c|c|c|}
\hline Description & Response & Percentage (\%) & Frequency \\
\hline Is there any routine screening and prevention of diseases? & Yes & 20 & 3 \\
& No & 80 & 12 \\
\hline Did you ever encounter any rejection of your milk by customers? & No & 100 & 15 \\
\hline
\end{tabular}

Since $100 \%$ of the farmers' milk was never rejected, it could be one of the leading factors that contribute to the syndromic acute gastroenteritis cases that have been reported in Guyana [24]. In 2009, the number of syndromic acute gastroenteritis cases reported by the Ministry of Public Health amounted to 131,012 [24]. The symptoms of acute gastroenteritis are associated with the symptoms of $E$. coli contamination. Hence, there may be a link between the milk and the number of acute gastroenteritis cases reported.

\section{CONCLUSIONS AND RECOMMENDATIONS}

Fifteen (15) milk samples were collected from fifteen (15) different farmers and tested for the presence of Escherichia coli and aerobic bacteria. The findings revealed that the raw cow milk was contaminated with Escherichia coli and aerobic bacteria and the various practices at the farm level may have been the contributory factors towards this contamination. Contamination levels for E. coli and aerobic bacteria were at the nonstandard and unsatisfactory level respectively according to the guidelines used. This indicates a potential source of milk-borne infections and raises a public health concern about its safety to consumers.

Since raw milk is an important vehicle for transmission of zoonoses and other pathogens, the high quantity of microbes implies that milk consumers in the study area are at a health risk. Indeed, this was supported by the detection of aerobic bacteria and E. coli at higher prevalence. Therefore, a survey should be conducted to determine the size of the population that consumes raw cow milk, and measures should be put in place to educate cattle farmers and consumers on the risk associated with raw milk consumption, in order to prevent zoonotic infections and foodborne diseases. Also, routine assessment on the quality of milk produced by small-scale livestock farmers and consume by many persons should be mandatory in order to prevent zoonotic infections. 
Evaluation of The Microbial Load and Identification of Possible Sources of Contamination of Raw Cow's Milk in Joanna, Black Bush Polder, Region 6, Guyana

\section{SOURCES OF FUNDING}

None.

\section{CONFLICT OF INTEREST}

None.

\section{ACKNOWLEDGMENT}

The authors expressed gratitude to the cattle farmers from Joanna and the staff of the Biology Department at John's Science Centre, University of Guyana, Berbice Campus, Tain, Guyana, South America.

\section{REFERENCES}

[1] Lanou, Amy Joy, Susan E. Berkow, and Neal D. Barnard. "Calcium, dairy products, and bone health in children and young adults: a reevaluation of the evidence." Pediatrics 115.3 (2005): 736-743.

[2] Chambers, J. V. "Dairy Microbiology Handbook." New York (2002): 39-90.

[3] Omore, A., Lore, T., Staal, S., Kutwa, J., Ouma, R., Arimi, S., and Kang'ethe, E. Addressing the public health and quality concerns towards marketed milk in Kenya. Smallholder Dairy Project Research and Development, Report 3. (2005).

[4] Rodojcic-Prodaova, D., and T. Necev. "Most common agents of subclinical mastitis in cows on private and communal farms in the Republic of Macedonia." Vet. Glasnik 45 (1991): 745-747.

[5] Eberhart, R.J. Coliform Mastitis. J. Am. Vet. Assoc., 170 (1977): 1160-1163.

[6] Parekh, T. S., and R. Subhash. "Molecular and bacteriological examination of milk from different milch animals with special reference to coliforms." Current Research in Bacteriology 1.2 (2008): 56-63.

[7] World Health Organization. Safer Food for Better Health. A Global WHO food strategy. pp. 2, (2009). Retrieved from: http://www.who.int/mip2001/files/2297/FoodsafetyStrategy.doc.

[8] Food hygiene. (2010). Retrieved https://web.archive.org/web/20151211131645/https://www.bupa.com.au/health-and-wellness/healthinformation/healthy-living/nutrition/eating/doc/food-hygiene.

[9] Shirima, G.M., Fitzpatrick, J., Cleaveland, S., Kambarage, D.M., Kazwala, R.R., Kunda, J. and Fren1ch, N.P. Participatory survey on zoonotic diseases affecting livestock keeping communities in Tanzania. Journal of Animal and Veterinary Advances 2.4 (2003): 253 - 258.

[10] Sivapalasingam, S., Friedman, C. R., Cohen, L., \&Tauxe, R. V. Fresh produce: a growing cause of outbreaks of foodborne illness in the United States, 1973 through 1997. Journal of food protection, 67.10 (2004): 23422353.

[11] Al-Tahiri, R. A comparison on microbial conditions between traditional dairy products sold in Karak and same products produced by modern dairies. Pakistan Journal of Nutrition 4.5 (2005): 345 - 348.

[12] Mungai, E. A., Behravesh, C., \& Gould, L. Increased Outbreaks Associated with Nonpasteurized Milk, United $\begin{array}{lllll}\text { States, 2007-2012.Emerging } \quad \text { Infectious } & \text { Diseases, } & 21.1 & \text { (2015): }\end{array}$ https://dx.doi.org/10.3201/eid2101.140447.

[13] Disassa, N., Sibhat, B., Mengistu, S., Muktar, Y., \&Belina, D. Prevalence and antimicrobial susceptibility pattern of E. coli 0157: H7 isolated from traditionally marketed raw cow milk in and around Asosa town, western Ethiopia. Veterinary medicine international, (2017).

[14] Vahedi, M., Nasrolahei, M., Sharif, M., \&Mirabi, A. M. Bacteriological study of raw and unexpired pasteurized cow's milk collected at the dairy farms and supermarkets in Sari city in 2011. Journal of preventive medicine and hygiene, 54.2 (2013): 120.

[15] United States Food and Drug Administration. Bacteriological Analytical Manual. Washington, D.C: Association of Official Analytical Chemists. (2002). Retrieved from: https://www.fda.gov/Food/FoodScienceResearch/LaboratoryMethods/ucm064948.htm 
[16] Welearegay, H., Yilma, Z., \&Tekle-Giorgis, Y. Hygienic practices and microbiological quality of raw milk produced under different farm size in Hawassa, southern Ethiopia. Agricultural Research and Reviews, 1.4 (2012): 132-142.

[17] Wallace, R. L. Bacteria count in raw milk. Dairy Cattle. Management, 1(2009): 4

[18] White, C. How Pasteurization Works. (2019). Retrieved from: https://science.howstuffworks.com/life/cellular-microscopic/pasteurization5.htm

[19] Home and Garden Information Centre. Safe Handling of Milk \& Dairy Products. (2007). Retrieved from: https://hgic.clemson.edu/factsheet/safe-handling-of-milk-dairy-products/

[20] Gwandu, S. H., Nonga, H. E., Mdegela, R. H., Katakweba, A. S., Suleiman, T. S., \&Ryoba, R. Assessment of raw cow milk quality in smallholder dairy farms in Pemba Island Zanzibar, Tanzania. Veterinary medicine international. (2018).

[21] Lejeune, J. T., Besser, T. E., \& Hancock, D. D. Cattle Water Troughs as Reservoirs of Escherichia coli 0157. Appl. Environ. Microbiol. 67.7(2001): 3053-3057.

[22] Faith, N. G., Shere, J. A., Brosch, R., Arnold, K. W., Ansay, S. E., Lee, M. S. \& Kaspar, C. W. Prevalence and clonal nature of Escherichia coli 0157: H7 on dairy farms in Wisconsin. Appl. Environ. Microbiol. 62.5 (1996): 15191525.

[23] Farm It. What happens if you don't milk cows? (2019). Retrieved from: https://farmityourself.com/whathappens-if-you-dont-milk-cows/

[24] Persaud, S., Mohamed-Rambaran, P., Wilson, A., James, C. and Indar, L. Determining the Community Prevalence of Acute Gastrointestinal Illness and Gaps in Surveillance of Acute Gastroenteritis and Foodborne Diseases in Guyana. Journal of Health, Population and Nutrition. 31.4 Suppl 1 (2013): S57. 